\title{
PEMANFAATAN INSTAGRAM SEBAGAI MEDIA ALTERNATIF IPA DALAM MASA PEMBELAJARAN JARAK JAUH (PJJ)
}

\author{
Wahyu Fajar Saputra \\ Mahasiswa Program Studi Pendidikan MIPA, Fakultas Pascasarjana, Universitas Indraprasta PGRI, JI. Nangka Raya \\ No.58 C, Jakarta, Indonesia \\ Email: wahyu787@gmail.com
}

\begin{abstract}
During the Corona Virus Disease-19 (Covid-19) pandemic, all of society elements are forced to work from home, including the education field. This forces educators to look for alternative media for Distance Learning. This study aims to prove that Instagram, as a social media, can be used as an alternative media in facing the recent Distance Learning. This research is a type of descriptive qualitative research by delivering observation questionnaires to students. The background of the research is derived from the fact that the teacher is lack of using social media in learning; in contrast, students are very often to use social media. From the research results conducted at Islamic Junior High School AlMakiyah Jakarta and MTS AL-Falah Jakarta, it is found that $63.1 \%$ of students use the Instagram application with an intensity of always using the Instagram application around 17\%, often using the Instagram application around $46.34 \%$, and sometimes using the Instagram application around $36.58 \%$. From these data, it is shown that Instagram is appropriate to be used as an alternative media in science learning during the Distance Learning Period because the Instagram application is very easy to be used and is the application often used by students in the Distance Learning period.
\end{abstract}

Keywords: Covid-19, Distance Learning, Instagram, Alternative Media, Science Media

\begin{abstract}
ABSTRAK
Pada masa pandemi Corona Virus Disease-19 (Covid-19) memaksa semua elemen masyarakat untuk beraktifitas dari rumah termasuk dunia pendidikan. Hal ini memaksa para pendidik mencari media alternatif guna berlangsungnya Pembelajaran Jarak Jauh (PJJ). Penelitian ini bertujuan untuk membuktikan media sosial Instagram dapat dimanfaatkan sebagai media alternatif dalam menghadapi Pembelajaran Jarak Jauh (PJJ) seperti ini. Penelitian ini merupakan jenis penelitian kualitatif secara deskriptif dengan memberikan angket observasi kepada siswa. Penelitian ini dilakukan berdasarkan latar belakang sangat kurangnya guru memanfaatkan media sosial dalam pembelajaran sedangkan siswa sangat sering menggunakan media sosial. Dari hasil penelitian yang dilakukan pada SMP Islam Al-Makiyah Jakarta dan MTS AL-Falah Jakarta didapatkan 63,1\% siswa menggunakan aplikasi Instagram dengan intensitas selalu menggunakan aplikasi instagram sekitar 17\%, sering menggunakan aplikasi instagram sekitar 46,34\% dan kadangkadang menggunakan aplikasi instagram sekitar 36,58\%. Dari data tersebut menunjukkan bahwa Instagram layak digunakan sebagai media alternatif dalam pembelajaran IPA dalam masa Pembelajaran Jarak Jauh (PJJ) dikarenakan aplikasi instagram sangat mudah digunakan dan merupakan aplikasi yang sering digunakan siswa dalam masa Pembelajaran Jarak Jauh..
\end{abstract}

Kata Kunci: Covid-19, Pembelajaran Jarak jauh, Instagram, Media Alternatif, Media IPA

Cara Sitasi: Wahyu F. S. (2021). Pemanfaatan instagram sebagai media alternatif ipa dalam masa pembelajaran jarak jauh (pjj). J-KIP (Jurnal Keguruan dan IImu Pendidikan), 2 (2), 81-90. 


\section{PENDAHULUAN}

Media pembelajaran bertujuan untuk mencapai tujuan dalam pembelajaran. Media Pembelajaran sebagai alat bantu dalam proses belajar mengajar adalah suatu kenyataan yang tidak bisa dipungkiri keberadaannya, karena keberadaan media sangat membantu tugas guru dalam menyampaikan materi pembelajaran dan pesan-pesan moril yang akan disampaikan kepada peserta didik. Guru menyadari bahwa tanpa bantuan media, maka materi pembelajaran sukar untuk dipahami oleh setiap peserta didik terutama materi pembelajaran yang membutuhkan visualisasi yang baik.

Menurut Heinich, dkk (1996) dalam Bambang Warsita (2008) mengungkapkan bahwa kata media merupakan bentuk jamak dari kata medium yang dapat diartikan sebagai perantara atau pengantar tejadinya komunikasi dari pengirim menuju. Criticos (1996) mengungkapkan media sebagai salah satu komponen komunikasi, sebagai pembawa pesan dari komunikator menuju komunikan. Berdasarkan pengertian tersebut, dapat dikatakan bahwa proses pembelajaran merupakan proses komunikasi dan interaksi antara guru dan siswa.

Sadiman (2007) mengungkapkan bahwa media adalah perantara atau pengantar pesan dari pengirim ke penerima pesan. Dalam bahasa Arab, kata media juga dapat diartikan sebagai perantara (wasail) atau pengantar pesan dari pengirim kepada penerima pesan (Arsyad, 2006: 3). Secara khusus, media dalam proses pembelajaran dapat kita diartikan sebagai alat-alat gambar, suara untuk memproses, menangkap, dan menyusun informasi berupa visual (verbal) serta audio.

Dari pendapat ahli tersebut dapat penulis disimpulkan bahwa media adalah perantara atau pengantar dari pengirim kepada penerima. Sehingga media sebagai komponen komunikasi khususnya dalam bidang pendidikan sebagai pengirim informasi dari guru kepada siswa.

Oemar Hamalik dalam Arsyad (2006) megungkapkan bahwa dengan pemakaian media pembelajaran dalam proses belajar mengajar dapat membangkitkan keinginan dan minat yang baru, membangkitkan motivasi dan rangsangan kegiatan belajar, dan bahkan membawa pengaruh-pengaruh psikologis terhadap siswa. Penggunaan media pembelajaran pada tahap orientasi pembelajaran akan sangat membantu keefektifan proses pembelajaran dan penyampaian isi materi pembelajaran tersebut.

Selain meningkatkan pemahaman materi pembelajaran, media juga dapat membantu siswa untuk membangkitkan motivasi dan minat belajar siswa. Dengan menyajikan media yang menarik dengan data yang terpercaya, yang memudahkan penafsiran dan memperjelas informasi membuat siswa menjadi tertarik

Angkowo dan Kosasih (2007) mengemukakan salah satu fungsi media pembelajaran adalah sebagai alat bantu pembelajaran yang ikut mempengaruhi situasi, kondisi dan lingkungan belajar dalam rangka mencapai tujuan pembelajaran yang telah diciptakan dan didesain oleh guru. Selain itu media dapat dimanfaatkan untuk memperjelas pesan agar tidak terlalu monoton. Memanfaatkan media secara tepat, kreatif dan bervariasi akan dapat meningkatkan keaktifan siswa.

Pandemi Covid-19 membuat semua aktivitas manusia terpaksa untuk melakukan segala kepentingan dari rumah saja. Salah satu yang terkena dampak dari covid-19 ini adalah dalam bidang pendidikan. Sekolah melakukan pembelajaran secara daring (Pembelajaran Jarak Jauh) sehingga guru harus mencari alternatif media yang digunakan dalam pembelajaran jarak jauh. Media ini harus digunakan dan dapat dengan mudah diakses oleh semua peserta didik dan guru. Untuk itu media yang digunakan adalah media sosial.

Media Sosial adalah alat bantu untuk menyampaikan informasi dari seseorang ke orang lain atau kelompok (organisasi), untuk mencapai tujuan individu maupun tujuan kelompok. Untuk lebih jelas di kemukakan oleh Nasrullah (2016) bahwa "media sosial dapat dilihat dari perkembangan bagaimana hubungan individu dengan perangkat media." Media memiliki peran yang penting dalam bidang pendidikan khususnya untuk tercapainya proses pembelajaran, termasuk pemanfaatan media sosial yang di dalamnya bermacam-macam konten dan fitur yang berisi berbagai bidang berupa informasi-informasi penting yang bersifat menyeluruh (universal).

Van Dijk (2013) dalam Nasrullah (2016) mengemukakan bahwa Media sosial adalah platform media yang memfokuskan pada eksistensi pengguna yang memfasilitasi mereka dalam beraktifitas 
maupun berkolaburasi, Karena itu media sosial dilihat sebagai fasilitator secara virtual yang bertujuan untuk menguatkan hubungan antar pengguna sekaligus sebagai sebuah ikatan sosial jarak jauh. Berbagai definisi, Dr.Rulli Nasrullah M.Si. dalam buku Media Sosial (2016), berkesimpulan bahwa Media Sosial merupakan perantara di internet yang memungkinkan penggunanya mempresentasikan dirinya maupun berinterakasi, saling berbagi, berkomunikasi, bekerja sama dengan pengguna lainnya, dan membentuk ikatan sosial secara tidak langsung."

Dari berbagai pengertian di atas peneliti menggaris bawahi bahwa di zaman teknologi informasi ini media sosial sangat dibutuhkan dengan media sosial yang mempunyai ciri khas tertentu. Yang kaitannya dengan hubungan sosial sesama manusia.

Dengan hadirnya teknologi internet tersebut telah lahir pula teknologi yang memudahkan masyarakat untuk berkomunikasi antara lain Electronic mail (E-mail), Line, WhatsApp, Facebook, Twitter, Instagram, Tiktok, Google Plus dan muncul beberapa website berbasis media sosial atau lebih dikenal dengan situs jejaring sosial. Situs jejaring sosial hadir dan digemari di banyak kalangan. Dalam survey APJII (Asosiasi Pengguna Jasa Internet Indonesia) tahun 2015 menyatakan bahwa sebanyak 87\% kegiatan utama masyarakat Indonesia yang mengakses internet untuk menggunakan media sosial.

Salah satu situs jejaring sosial yang menjadi fenomena di banyak kalangan adalah Instagram. Instagram hadir dengan dua versi berbeda. Versi pertama adalah dalam berbentuk website (web version) yang dapat diakses langsung di PC atau laptop dengan mengunjungi laman nya www.instagram.com. Versi kedua adalah versi seluler (mobile version), dengan versi tersebut pengguna dapat menggunakan instagram tersebut pada handphone atau smartphone.

Dalam penggunaanya, aplikasi sosial instagram dapat memberikan efek ketagihan yang terus menerus membuat penasaran update kabar terbarunya. Dengan adanya fitur upload video dan foto, aplikasi sosial instagram tersebut mampu mempengaruhi penggunanya. Terdapat beragam foto dan video yang diupload pengguna instagram mampu kita lihat, yang bijaksana ataupun yang kurang sopan. Belum lagi apabila aplikasi instagram tersebut diakses pada saat sekolah ataupun jam kerja, tentunya sangat mengganggu pekerjaan atau pun jam belajar-mengajar.

Namun, dibalik itu semua sebenarnya instagram mampu menjadi alternatif yang bermanfaat pada dunia pendidikan. Terkait dengan penggunaan instagram yang telah menjadi racun dikalangan pelajar mampu menjadi stimulus siswa guna meningkatkan motivasi belajar siswa. Pendidik mampu melihat celah kekurangan yang menyebabkan siswa bosan dan menutupi kekurangan tersebut dengan mengikuti perkembangan teknologi yang berkembang dan diminati siswa. Dengan mengikuti minat siswa, maka mampu menstimulus siswa untuk giat belajar. Sistem pembelajaran yang konvensional dan monoton membuat siswa bosan dan tidak tertarik dengan materi yang disampaikan.

Banyak penelitian membuktikan bahwa aplikasi media sosial dalam pembelajaran, menunjukkan bahwa penggunaan sosial media dapat meningkatkan kualitas pembelajaran dan hasil belajar. Stainbank \& Gurr (2016) menyatakan bahwa penggunaan media sosial dapat meningkatkan kualitas pembelajaran dan hasil belajar akuntansi dengan menggunakan media sosial Facebook dan Twitter. Erika, Yanto, \& Kasidi (2018) menemukan perbedaan yang signifikan pada hasil belajar akuntansi yang menggunakan media sosial Facebook dan tidak menggunakan Facebook. Menurut Tadros (2011) Adanya teknologi menciptakan pembelajaran di kelas yang lebih menarik dan inovatif yang membuat siswa lebih tertarik dan termotivasi dalam proses pembelajaran, jika media yang digunakan benar. Media sosial memberikan siswa kemampuan untuk berpikir kritis dan kreatif, yang memungkinkan siswa untuk berkolaborasi dengan guru yang lebih efektif dan menarik bagi rekan-rekan mereka dan bahkan dapat menjangkau lintas budaya. Jadi, penggunaan media sosial sebagai media pembelajaran dapat meningkatkan motivasi belajar siswa.

Dengan adanya pemaparan latar belakang di atas, peneliti bermaksud melakukan kombinasi antara media pembelajaran dengan penggunakan Instagram yang sangat digemari siswa. Oleh karena itu, maka peneliti merasa perlu diadakan penelitian mengenai "Pemanfaatan Instagram Sebagai Media Alternatif IPA dalam Masa Pembelajaran Jarak Jauh". 


\section{METODE PENELITIAN}

Penelitian ini adalah jenis penelitian deskriptif yaitu penelitian yang bertujuan membuat deskripsi secara sistematis, faktual dan akurat tentang fakta-fakta dan sifat- sifat populasi atau obyek tertentu, dengan menggunanakan metodologi riset kualitatif. Bentuk penelitian yang digunakan dalam penelitian ini adalah penelitian kualitatif dengan metode penelitian deskriptif.

Menurut Hadari Nawawi (2007) metode deskriptif adalah prosedur pemecahan masalah yang diselidiki dengan menggambarkan/ melukiskan keadaan subyek/obyek penelitian (seseorang, lembaga, masyarakat dan lain-lain) pada saat sekarang berdasarkan fakta-fakta yang tampak sebagaimana adanya.

Teknik pengumpulan data pada penelitian ini adalah observasi. Menurut Satori (2009:105) "observasi adalah pengamatan terhadap suatu objek yang diteliti baik secara langsung maupun tidak langsung untuk memperoleh data yang harus dikumpulkan dalam penelitian".Dalam observasi ini, peneliti terlibat dengan kegiatan sehari-hari orang yang sedang diamati dan meminta bantuan guru sekolah lain sebagai pembanding untuk melengkapi peneliatian.Dengan melalui pengamatan secara langsung terhadap objek penelitian yaitu siswa kelas VIII di SMP Islam Al-Makiyah kemudian juga objek penelitian lain yaitu siswa kelas VIII di MTS AL-Falah Jakarta, peneliti mencatat semua peristiwa yang berkaitan dengan penelitian, alat yang digunakan adalah pedoman observasi.

Dalam observasi peneliti mengadakan pengambilan data melalui Google Form yang disebar kepada seluruh siswa kelas VIII di SMP Islam AL-Makiyah dan MTS AL-Falah, Angket ini dibuka selama 6 hari dari tanggal 20 maret 2021 sampai dengan 25 maret 2021 sehingga didapatkan jumlah observer sebanyak 65 siswa dari kelas VIII.

Menurut Satori (2009) "studi dokumentasi yaitu mengumpulkan dokumen dan data-data yang diperlukan dalam permasalahan penelitian lalu ditelaah secara intens sehingga dapat mendukung dan menambah kepercayaan dan pembuktian suatu kejadian". Studi dokumentasi sebagai pengambilan data sekunder mencatat dan mendokumentasikan, diperoleh dari instansi yang terkait dengan masalah penelitian baik dari sumber catatan dan arsip-arsip tentang sikap dan perilaku siswa, alat yang digunakan adalah catatan dan arsip-arsip tentang sikap dan perilaku siswa.

\section{HASIL DAN PEMBAHASAN}

Penelitian dilaksanakan pada tahun ajaran 2020-2021 atau dalam masa Pembelajaran Jarak Jauh. Responden pada penelitian ini adalah siswa kelas 8 dari SMP Islam AI-Makiyah Jakarta dan MTS Al-Falah Jakarta. Adapun jumlah responden yang berhasil didapat sebanyak 65 responden.

Berdasarkan pengambilan data kepada responden bahwa platform media sosial Instagram merupakan platform yang sering digunakan oleh siswa (sekitar 63,1\%) setelah aplikasi Whatsapp (90,8\%) dan Youtube (66,2\%). Dari data tersebut dapat disimpulkan bahwa penggunaan aplikasi Instagram cukup dominan dibandingkan dengan platform yang serupa. Pengguna Whatsapp mendominasi karena sebagian besar pengguna Smartphone pasti menginstall aplikasi Whatsapp. WhatsApp adalah sebuah aplikasi chatting pada yang biasanya selalu tersedia ataupun di install dalam smartphone (ponsel pintar). WhatsApp adalah aplikasi chatting lintas platform yang memungkinkan kita untuk bertukar pesan tanpa harus membayar biaya untuk SMS, semua smartphone dapat berkirim pesan satu sama lain dengan aplikasi Whatsapp. Sedangkan aplikasi Youtube, adalah aplikasi berbasis video. Sehingga kita dapat menonton video ataupun mengupload video yang dapat dilihat orang banyak. Namun berbeda dengan Instagram yang semua fitur dalam Whatsapp maupun Youtube dapat tersedia lengkap di dalam media sosial Instagram. Sehingga dilihat dari fitur, media sosial Instagram Cukup lengkap 


\section{Penggunaan Aplikasi Media Sosial}

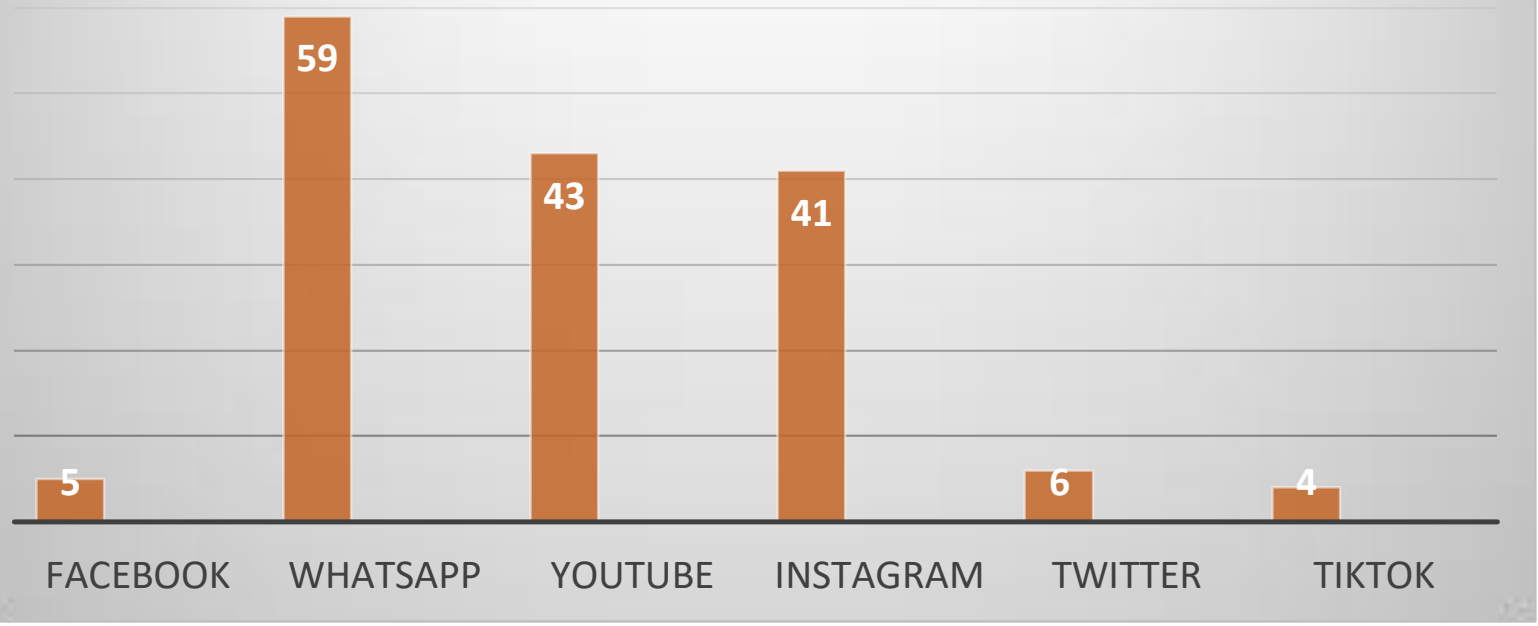

Gambar 1. Grafik Penggunaan Media Sosial

Sebagian besar siswa menggunakan media sosial hanya cenderung ikut-ikutan teman, apalagi dalam masa pandemi (Pembelajaran Jarak Jauh), siswa membutuhkan interaksi jarak jauh yang efektif dan menarik. Instagram dianggap unggul karena memiliki fitur yang sangat menarik seperti upload foto dan video, fitur live instagram, instagram story, instagram feed, bahkan video call. Fitur tersebut menjadi contoh untuk media sosial lainnya. Instagram juga dianggap menjadi akun yang wajib dimiliki karena banyak publik figur untuk berinteraksi secara langsung melalui media sosial Instagram. Disamping itu, banyak juga yang menggunakan akun Instagram sebagai sarana media penjualan. Namun dengan cukup lengkapnya fitur dalam Instagram sangat disayangkan apabila tidak dimanfaatkan dalam pembelajaran. Berikut penulis sajikan grafik penggunaan fitur dalam instagram yang dilakukan oleh responden. 


\section{Penggunaan Fitur-fitur dalam Instagram}

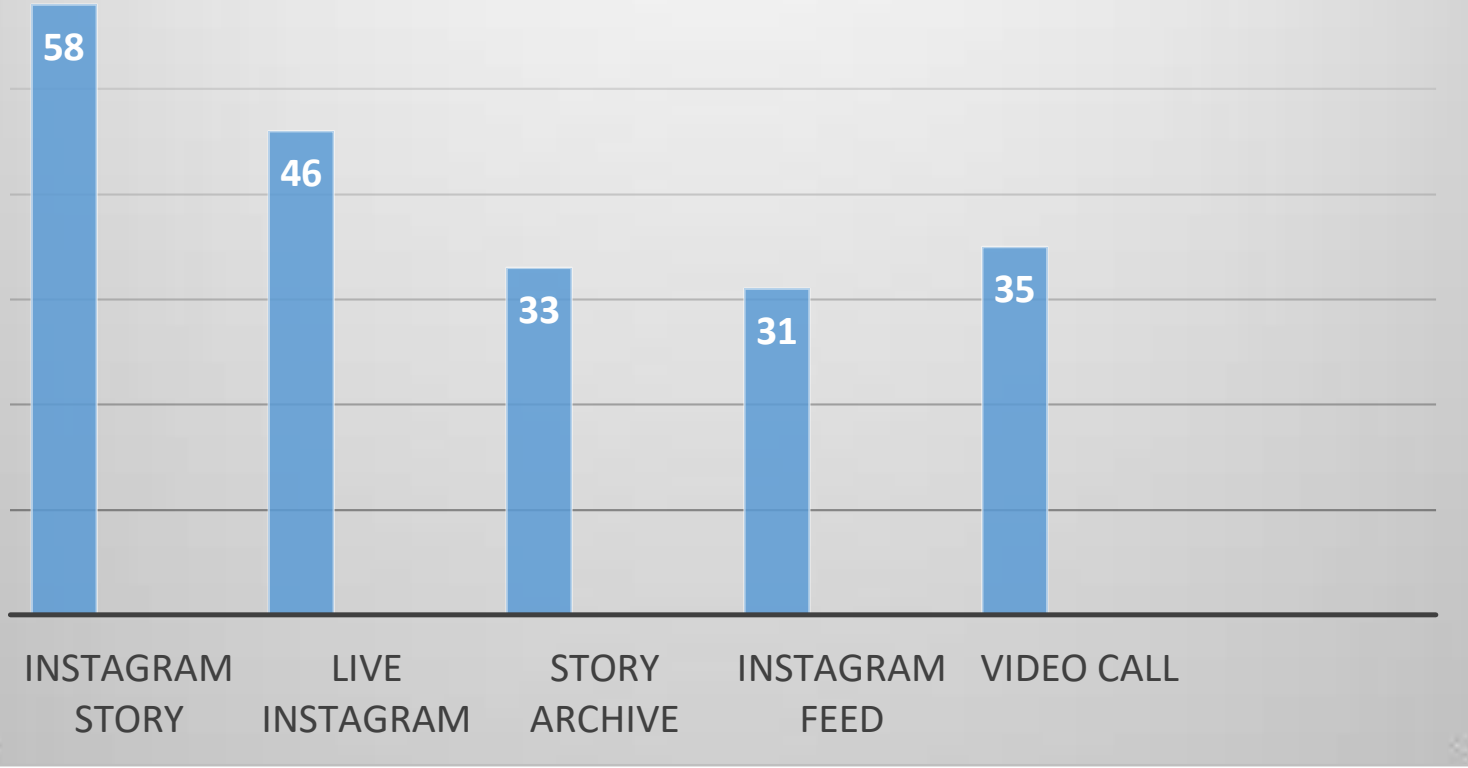

Gambar 2. Grafik penggunaan fitur dalam Instagram

Dari grafik tersebut dapat kita lihat persentase penggunaan fitur instagram yaitu Instagram Story sebanyak $89,2 \%$ disusul dengan live inetagram sebanyak $70,8 \%$, Video call sebanyak $53,8 \%$, Story archive dan story highlight sebesar 50,8\%, dan instagram feed sebanyak 47,7\%. Penggunaan Instagram Story paling banyak karena biasanya siswa menggunakan instagram untuk melihat kegiatan sehari-hari seseorang yang diikutinya. Selain kegiatan, biasanya terdapat juga informasi yang cukup update yang terdapat dalam Instagram story. Namun seharusnya para pendidik dapat memanfaatkan fitur ini dalam kegiatan pembelajaran jarak jauh.

\section{A. Instagram Story}

Instagram Story sebenarnya adalah modifikasi fitur dari aplikasi Snapchat. Saat ini jumlah pengguna Instagram Story berhasil mencapai pengguna aktif sebanyak 200 juta perhari dari seluruh dunia. Pengguna harian Instagram Story jauh melebihi pengguna aktif Snapchat. Jumlah pengguna Snapchat turun hingga 82\% setelah Instagram merilis fitur Instagram Story. Jumlah pengguna Instagram Story yang terus bertambah, menandakan keberhasilan Instagram dalam menarik minat pengguna media sosial dengan menggunakan fitur Instagram Story. Fitur ini sebenarnya mirip dengan fitur yang sudah dimiliki Instagram sebelumnya yang selalu memfokuskan untuk berbagi foto dan video.Tetapi yang dapat membedakannya adalah pada sisi tujuannya, dan juga sifatnya tidak tetap (semetara).

Maksudnya adalah fitur ini lebih cocok digunakan dalam kondisi yang tidak memerlukan intensitas waktu yang lama (hanya sebentar). Dan sifat sementara atau tidak tetap disini adalah ketika kita membagikan sebuah momen foto atau video menggunakan fitur Instagram Story, foto atau video kita ini hanya dapat bertahan selama 24 jam, yang artinya foto atau video tersebut akan otomatis terhapus dari Instagram apabila sudah melebihi dari 24 jam. Sangat berbeda pastinya ketika kita menggunakan Instagram pada umumnya, dimana foto atau video kita akan tetap tersimpan selamanya. Perbedaan yang lain antara Instagram Story dan Instagram Feed adalah masalah durasi. Jika menggunakan Instagram 
Feed, kita bisa membagikan video dengan durasi maksimal 1 menit dengan maksimal 10 video, akan tetapi jika menggunakan fitur instagram Story kita hanya dapat membagikan video dengan durasi maksimal 30 detik.

Seiring pembaharuan aplikasi Instagram, fitur dalam Instagram Story pun semakin beragam yang dapat dimanfaatkan dalam Pembelajaran Jarak Jauh.

\section{Poll Stickers}

Fitur Instagram pertama yang efektif untuk mengajak siswa agar mau terlibat dengan konten yang diberikan atau meningkatkan respon dan partisipasi siswa untuk aktif dalam pembelajaran adalah dengan menyajikan poll stickers. Fitur dalam poll stickers ini terbilang cukup sederhana dan mampu mengajak siswa untuk mau mengisinya.

2. Question Stickers

Konten question stickers ini dapat membantu guru untuk mengetahui pengalaman dan pemahaman siswa dengan pertanyaan-pertanyaan yang membangun.

\section{Quiz Stickers}

Quiz Sticker dapat memudahkan guru membuat pertanyaan dalam bentuk pilihan ganda yang nantinya akan dijawab secara langsung oleh siswa, sehingga memberikan pengalaman yang menarik bagi siswa dengan mengerjakan soal dengan cara yang menarik.

4. Chat Stickers

Dalam tool ini, kita dapat membuat forum diskusi yang berisikan maksimal 32 partisipan. Dengan menyajikan konten ini, kita dapat membuat sbuah percakapan mengenai topik-topik yang ingin didiskusikan antara siswa dan guru.

\section{B. Live Instagram}

Live Instagram memiliki persentase $70,8 \%$. Karena biasanya siswa dapat melihat informasi atau hiburan terkini melalui live instagram yang dibuat oleh salah satu tokoh yang diikutinya. Hal ini dapat dimanfaatkan guru dalam pembelajaran jarak jauh dengan diadakanya pembelajaran secara daring melalui fitur Live Instagram. Live Instagram ini dapat menjadi media alternatif selain penggunaan Zoom dan Google Meet serta memanfaatkan media sosial yang sering digunakan oleh siswa.

\section{Video Call}

Video Call memiliki persentase sebanyak $53,8 \%$. Fitur Video call ini cukup banyak digunakan lantaran butuhnya seseorang interaksi melalui jarak jauh dengan bertatap muka apalagi dalam masa pandemi seperti ini. Ini juga bisa dilakukan oleh guru terhadap siswa dengan menggunakan fitur Video Call, guru dapat bertatap muka secara daring dengan siswa secara 2 arah. Hal ini dapat dimanfaatkan dalam pembelajaran khusus yang dilakukan oleh guru dan siswa.

\section{Story Archive dan Story Highlight}

Story Archive dan Story Highlight memiliki persentase 50,8\%. Fitur Instagram Story hanya dapat dilihat dalam tempo waktu 24 jam (1 hari) yang artinya lewat dari itu tidak dapat dilihat lagi oleh pengikutnya, untuk itu diperlukan fitur untuk mengarsipkan story agar dapat dilihat kembali. Hal ini dimungkinkan dalam pembelajaran, setelah guru membuat materi (catatan) atau membuat quiz apabila ingin dilihat lagi oleh siswa kembali yaitu dengan cara mengarsipkannya menggunakan Story Archive dan Story Highlight. Dengan mengarsipkan gambar atau video yang dibuat, guru juga dapat membuat kategori untuk mempermudah siswa dalam mencari materi yang ingin dilihat kembali.

\section{E. Instagram Feed}

Instagram Feed memiliki persentase 47,7\%. Hal ini dikarenakan fitur ini adalah fitur yang sangat biasa dari aplikasi Instagram ataupun aplikasi yang serupa seperti Facebook ataupun Twitter. Namun fitur Instagram Feed ini dapat dimanfaatkan guru dalam memberikan materi dalam Pembelajaran Jarak Jauh 
melalui instagram dengan gambar dan video yang menarik, sehingga siswa dapat tertarik untuk menyimak materi yang diberikan guru.

Aplikasi Instagram sangat cocok dijadikan media pembelajaran secara online atau daring hal ini dikarenakan aplikasi Instagram sangat mudah untuk digunakan dan merupakan aplikasi yang sangat dikenal dalam kalangan generasi milenial. (Sidiq Aditia,2020) Beberapa fitur dalam aplikasi Instagram juga sangat mendukung proses pembelajaran diantaranya adalah feed post yang berguna untuk memberikan gambaran awal tentang materi yang hendak disampaikan kemudian intagram $t v$ yang berguna untuk guru supaya dapat menjelaskan atau menerangkan materi yang hendak disampaikan dan Instagram live yang berguna untuk proses tanya jawab seputar materi pembelajaran yang disampaikan sehingga siswa dan guru dapat berinteraksi serta melalui fitur live Instagram guru juga dapat mengabsen siswanya (Ahmad Veygid,dkk, 2020).

\section{KESIMPULAN}

Dari hasil penelitian dapat penulis simpulkan bahwa pemanfaatan Instagram pada masa pandemi Covid-19 ini layak digunakan oleh siswa sebagai alternatif media pembelajaran jarak jauh. Adapun fiturfitur yang dapat digunakan dalam pembelajaran IPA menggunakan instagram antara lain adalah Instagram Story, Live Instagram, Video Call, Story Archive dan Story Highlight serta Instagram Feed. Beberapa fitur tersebut dapat berjalan secara maksimal dalam pembelajaran IPA apabila guru dapat memanfaatkan fitur tersebut untuk pembelajaran IPA.

Diharapkan kedepannya siswa dapat memanfaatkan aplikasi Instagram dalam bidang pendidikan khususnya IPA. Karena dalam media sosial Instagram terdapat fitur Artificial Intelligence (Al) yang memungkinkan sering munculnya gambar atau video yang sering dilihatnya. Ketika siswa melihat hal-hal yang berbau pendidikan dan sains dalam instagram, maka akan sering muncul juga gambar dan video yang berbau sains dan pendidikan dalam berandanya. Selain itu diharapkan Instagram sebagai media pembelajaran secara daring pada masa pandemi ini yang dimanfaatkan untuk pembelajaran dan berinteraksi.

\section{REKOMENDASI}

Penelitian ini dapat dikembangkan menjadi penelitian pengembangan (R\&D) untuk memanfaatkan lebih aplikasi Instagram sebagai media pembelajaran IPA

\section{UCAPAN TERIMAKASIH}

Ucapan terimakasih diberikan kepada Orang tua yang senantiasa mendukung dan mendoakan sehingga dapat menulis penelitian ini dengan baik, tak lupa untuk dosen Pendidikan MIPA, Fakultas Pascasarjana Universitas Indraprasta yang mengarahkan serta membimbing penulis sehingga tercipta penelitian ini, lalu untuk Guru yang terlibat yaitu guru IPA di SMP Islam Al-Makiyah dan Guru IPA di MTS Al-Falah Jakarta serta siswa yang terlibat dalam penelitian ini sehingga penelitian ini dapat berjalan dengan baik.

\section{DAFTAR PUSTAKA}

Komariah, A \& Djam'an Satori. (2012). Metodologi Penelitian Kualitatif. Bandung: Alfabeta

Aditia, S. (2020). Inovasi Pembelajaran Berbasis Aplikasi Mobile Pada Masa Pandemi Covid-19. [Online]. Tersedia : https://osf.io/wim5k/download

Angkowo, R \& A. Kosasih. (2007). Optimalisasi media pembelajaran. Jakarta: PT. Grasindo.

Arief S. Sadiman. (2007). Media Pendidikan: Pengertian, Pengembangan, Dan Pemanfaatannya. Jakarta: PT. Raja Grafindo Persada.

Arsyad, A. (2006). Media Pembelajaran. Jakarta: PT. Rajagrafindo Persada.

Criticos. (1996). Media selection. Plomp, T., \& Ely, D. P. (Eds.): International Encyclopedia of Educational Technology, 2nd edition. New York: Elsevier Science, Inc. 
Erika, K., Yanto, T., \& Kasidi. (2018). Perbedaan hasil belajar pelajaran akuntansi dengan menggunakan media sosial dan tidak menggunakan media sosial. JurnalEcodunamika. Vol. 1 No.1. Hal. 1-9.

Gultom, J. (2010). Pemanfaatan Media Dalam Proses Belajar Mengajar. Jurnal Universitas Negeri Medan.

Hamalik, O. (1994). Media Pendidikan. Bandung: Citra Aditya Bakti.

Nawawi, H. (2007). Metode penelitian Bidang Sosial. Yogyakarta : Gadjah Mada University Press.

Nasrullah, R. (2016). Media Sosial Perspektif Komunikasi, Budaya, Sosioteknologi. Cet.kedua. Simbiosa Rekatama Media : Bandung.

Stainbank, L \& Gurr (2016). The use of social media platforms in a first year accounting course. Meditari Accountancy Research. Vol 24 No 3 Hal 318-340.

Tadros, M. (2011). A social media approach to higher education. In Educating Educators With Social Media Cutting-edge Technologies in Higher Education. Emerald Group Publishing Limited, Bingley. Vol. 1 Hal. 83-105. [Online]. Tersedia : https://doi.org/10.1108/S20449968(2011)0000001007

Veygid, Ahmad, dkk. (2020). Analisis Fitur Dalam Aplikasi Instagram Sebagai Media Pembelajaran Online Mata Pelajaran Biologi Untuk Siswa Sekolah Menengah Atas. ALVEOLI: Jurnal Pendidikan Biologi. Vol 1 No. 1 hal 39-48.

Warsita, B. (2008) Teknologi Pembelajaran: Landasan \& Aplikasinya. Jakarta: Rineka.

Wati, E, R. (2016). Ragam Media Pembelajaran. Yogyakarta: Kata Pena. 
